\title{
Interspecific variation in growth and tree water status of conifers under water-limited conditions
}

\author{
Adriana Leštianska $^{1 *}$, Peter Fleischer Jr. ${ }^{1,2}$, Peter Fleischer ${ }^{1}$, Katarína Merganičová ${ }^{1,3}$, Katarína Střelcová $^{1}$ \\ ${ }^{1}$ Technical University in Zvolen, Faculty of Forestry, T.G. Masaryka 24, 96001 Zvolen, Slovakia. \\ 2 Institute of Forest Ecology, Slovak Academy of Sciences, Department of Plant Ecophysiology, Štúrova 2, 96053 Zvolen, Slovakia. \\ ${ }^{3}$ Czech University of Life Sciences Prague, Faculty of Forestry and Wood Sciences, Kamýcká 129, 16500 Praha 6 - Suchdol, Czech \\ Republic. \\ * Corresponding author. Tel.: +421 455206 268. E-mail: adriana.lestianska@tuzvo.sk
}

\begin{abstract}
We monitored seasonal dynamics of stem water status of four coniferous species (Abies alba, Larix decidua, Picea abies and Pinus sylvestris) planted at the Borová hora Arboretum (300 m a.s.1., Zvolen valley, Central Slovakia) beyond their ecological and production optima, in the region with warmer and drier climate compared to the sites of their origin. Species-specific stem water deficit and maximum daily shrinkage were extracted from diurnal band dendrometer records of stem circumference recorded by digital band dendrometers DRL26 installed on five trees per species, and correlations with environmental variables were analysed. The seasonal stem circumference increment of all tree species was higher in 2017 than in the drier and hotter year of 2018. The greatest seasonal stem circumference increment in the observed periods of 2017 and 2018 was observed for A. alba and P. sylvestris, respectively. The highest and lowest values of daily and seasonal stem water deficit were observed for L. decidua and A. alba, respectively. The analysis of trees' short-term response to extreme climate events seems to be the promising and suitable method for detecting tree species tolerance towards drought.
\end{abstract}

Keywords: Dendrometer; Circumference changes; Stem water deficit; Drought; Stem shrinkage; Wavelet analysis.

\section{INTRODUCTION}

Projections of near future climate indicate increases in temperature and climate variability (IPCC, 2013), which are associated with increases in the frequency, severity and duration of climatic extremes in Europe (Will et al., 2013). These climatic extremes, i.e. storms, heat waves and severe drought periods, have become important drivers of forest ecosystem dynamics (Allen et al., 2015; IPCC, 2014). Due to the wide span of the provided and expected ecosystem services, mountainous and submontane forests have long been a subject of increased public interest. In the past, mountainous forests were considered stable because of their higher level of naturalness, long-term adaptation to extreme climate conditions, and high genetic and structural diversity. It is very probable that under changing climatic conditions, forest ecosystems will be more disturbed and ecosystem services will be provided at a level below their natural potential (Hlásny et al., 2011). Due to climate change, abiotic environmental factors create serious threats to ecological stability and forest production, and can cause change of tree species composition in forest ecosystems (Teskey et al., 2015). Tree response to climate depends on tree species, age, competition, site conditions and provenances (Spiecker, 2002). The strong need to adapt many forests to future climate conditions through changes in tree species composition is frequently in stark contrast to the dearth of information about the suitability of individual species and their provenances for projected future conditions (IPCC, 2014; McDowell and Allen, 2015). Given recent climatic trends, it is crucial to understand the plasticity and adaptiveness of forest trees in order to evaluate their current and future responses to changing climatic conditions. Hence, substitute species that are able to fulfil the current socio-economic requirements of forests must be considered, in particular at the current boundaries of tree species distribution (Bolte et al., 2009).

Temperature increase along with unchanged precipitation leads to significantly lower forest growth and production, particularly at lower elevations. Soil water availability and weather conditions have been repeatedly identified essential for tree growth and seasonal stem circumference changes (Ježík et al., 2016; Oberhuber et al., 2014). Daily stem circumference variation results from a combination of water- and growth-induced radial changes that provide us with complex information on seasonal environmental changes. The close lateral linkage of water conducting xylem with phloem translates changes in tree water status directly to shrinking and swelling of non-lignified tissues in bark and phloem (Zweifel and Häsler, 2001). These two opposite processes result from the changing water potential gradient in the plant (Zweifel et al., 2001). Depending on the species, variation in stem radius can additionally be attributed to the elastic behaviour of wood tissues (Perämäki et al., 2001), particularly xylem (Zweifel et al., 2014). Xylem elasticity is a function of wood density (Scholz et al., 2008) and/or specific tissue elasticity (Zweifel et al., 2014). Drought affects tree water status and impairs radial stem growth, because cell division and cell enlargement require adequate cell turgor (Zweifel et al., 2006). Automated band dendrometres are used for nondestructive continuous monitoring of circumference variation dynamics and small changes in stem water content with high temporal resolution. Stem water deficit has been shown to correlate with stem water potential and leaf water potential in trees (Ehrenberger et al., 2012; Offenthaler et al., 2001). Chan et al. (2016) reported that radial changes are approximately linearly proportional to changes in stem water potential. For transpiration trees first use water stored in crowns, and after their depletion the water from stem tissues is utilised (Čermák et al., 2007; Zweifel et al., 2001). Hence, stem water deficit 
does not necessarily represent the 'real' water deficit in trees, but is a valuable indirect measure for detecting physiological responses to water deficits (Oberhuber et al., 2015; Zweifel et al., 2005).

Norway spruce (Picea abies (L.) Karst.) has been extensively grown in a wide spectrum of climatic conditions (Caudullo et al., 2016). Nowadays, it is well known that spruce is sensitive to extreme drought events that affect its growth rate and overall vitality (Vitali et al., 2017). Silver fir (Abies alba Mill.) is a coniferous species native to Europe, with a geographical distribution largely limited to the Alpine and the Carpathian ranges. Until recently, silver fir was considered a species that prefers cold and moist climate (Ellenberger, 2009). There are indications that silver fir might be more suitable for future European climate as it grew well under warmer-than-present conditions during the mid-Holocene (Ruosch et al., 2016). On the other hand, Aussenac (2002) and Battipaglia et al. (2009) reported that silver fir is highly sensitive to drought and is a species typically affected by drought-induced decline at its southern and lower altitude margins. Scots pine (Pinus sylvestris L.) is known as a drought-tolerant species. However, according to Bouriaud and Popa (2009), P. sylvestris will respond very strongly to climate fluctuations. Its productivity could decline at localities exposed to water deficit as pine is already encountered on dry sites. European larch (Larix decidua Mill.) is typical for mountainous regions (Geburek, 2010). At lower altitudes, it is considered to be a non-native species and studies on larch growing at lower altitudes are less common. As the text above indicates, our study focuses on four tree species with different demands on environment and sensitivity to drought and climatic extremes. Our aim was to assess the behaviour of these species outside their ecological and growth optima. From band dendrometer records (BDR) we determined stem circumference variation, tree water status (maximum daily shrinkage (MDS) and stem water deficit $(\Delta \mathrm{W})$ ) of selected coniferous species (Abies alba, Picea abies, Larix decidua and Pinus sylvestris) growing at the same site located in warmer and drier conditions than their natural habitats, and: i) analysed their growth responses to environmental conditions; ii) compared seasonal development of tree water status characteristics (MDS and $\Delta \mathrm{W}$ ) of coniferous tree species exposed to drier and hotter conditions than in their natural habitats. Following Oberhuber et al. (2015), we assume that drier and hotter conditions will cause greater sensitivity of tree species manifested by the occurrence of periodic phenomena on the daily basis.

\section{MATERIAL AND METHODS Study area}

Our research was performed in Borová hora Arboretum $\left(19^{\circ} 08^{\prime} 12.30^{\prime \prime} \mathrm{E}, 48^{\circ} 35^{\prime} 44.22^{\prime \prime} \mathrm{N}\right.$, ca. $350 \mathrm{~m}$ a.s.l.) situated in Zvolen valley (Central Slovakia). Borová hora Arboretum is located on mild 5-10\% slopes with south-west aspect. The soil type is cambisol. From the climatic point of view, this area is situated in the temperate climatic zone with temperate CentralEuropean climate. The area belongs to a warm and a slightly warm region with cold winter. Average annual air temperature is $7.9^{\circ} \mathrm{C}$ and annual precipitation total is $651 \mathrm{~mm}$. Average temperature and precipitation total during a vegetation season (April-September) is $14.7^{\circ} \mathrm{C}$ and $377 \mathrm{~mm}$, respectively. Longterm averages representing the period 1961-1990 were provided by the Slovak Hydrometeorological Institute from a nearby meteorological station of Sliač (313 m a.s.1.). QuercetoFagetum community represents potential forest vegetation at the site (https://geo.enviroportal.sk/atlassr).
The provenances of the studied species (Picea abies, Abies alba, Pinus sylvestris and Larix decidua) were planted at four homogeneous research plots within the arboretum, each representing single species. At each plot, five adult trees of similar age and size (Table 1) were selected for the purpose of this study. The selected provenances originate from Slovakia and similar altitudes. In the arboretum, they grow beyond their ecological and production optima, in the region with warmer and drier climate than their original natural habitats (Table 1).

\section{Dendrometers}

Stem circumference variations were recorded using highresolution automatic band dendrometers DRL 26 (EMS Brno, $\mathrm{CZ}$ ). Dendrometers were installed on 20 sample trees (5 trees per species). Circumference measurements were recorded in 20-min intervals.

\section{Environmental data}

Meteorological data were recorded with an automatic meteorological station (EMS Brno, CZ) installed at an open area near study plots $(80-150 \mathrm{~m}$ from their centres). The meteorological station recorded global radiation $\left(\mathrm{GR}, \mathrm{W} \cdot \mathrm{m}^{-2}\right)$, air temperature $\left(\mathrm{AT},{ }^{\circ} \mathrm{C}\right)$, relative air humidity $(\mathrm{RH}, \%)$ and precipitation $(\mathrm{P}, \mathrm{mm})$. Vapour pressure deficit (VPD, Pa) was calculated from air temperature and relative humidity. At each study plot, soil water potential (SWP, Pa) was measured under forest canopy at 15, 30 and $50 \mathrm{~cm}$ soil depths (gypsum blocks and MicroLog SP3, EMS Brno, CZ). From these values, average values of SWP from all depths were calculated per plot.

\section{Tree water status}

Stem water deficit $(\Delta \mathrm{W}, \mathrm{mm})$ was quantified from dendrometer records de-trended for growth according to Ehrenberger et al. (2012). A 'growth line' was constructed by drawing lines between the daily maximum stem circumference values and the next equal stem circumference value, thus ignoring periods of incomplete stem circumference recovery due to stem shrinkage induced by water shortage. In the phases where the stem circumference values exceeded the previous maxima, the growth line followed the increasing values of stem circumference. In the following, stem water deficit was determined as a difference in stem size measured by dendrometers under low water availability conditions relative to the stem size under fully hydrated conditions $(\Delta \mathrm{W}=0)$ (Oberhuber et al., 2015) (Figure 1). Hence, increasingly negative values of $\Delta \mathrm{W}$ indicate increasing dehydration of water storage pools.

Maximum daily shrinkage (MDS, $\mathrm{mm}$ ) is a difference between the morning maximum and afternoon minimum at a particular day (diurnal amplitude). MDS reflects the daily cycle of water uptake and loss (Figure 1). Both stem water deficit and maximum daily shrinkage were calculated using special routines in "DendrometeR" package (van der Maaten et al., 2016).

\section{BDR and environmental variables}

The Spearman rank-correlation coefficients were calculated to explore the relationship between daily environmental variables (global radiation, precipitation, relative air humidity, vapour pressure deficit, air temperature and soil water potential) and water status characteristics extracted from BDR $(\triangle \mathrm{W}$ and MDS). Temporal variability of correlations of $\Delta \mathrm{W}$ and MDS to environmental variables was evaluated with 
Table 1. Basic site characteristics of the original location of the selected tree species provenances and stem diameter measured at $1.3 \mathrm{~m}$ breast height (DBH) at the beginning of 2017. (E - elevation, T - long-term average of air temperature, $\mathrm{P}$ - long-term average of precipitation; long-term averages of the original location represent the period 1961-1990).

\begin{tabular}{lllccccc}
\hline Species & Orographic unit & Locality & $\begin{array}{c}\mathrm{E} \\
(\mathrm{m} \text { a.s.l.) }\end{array}$ & $\begin{array}{c}\mathrm{T} \\
\left({ }^{\circ} \mathrm{C}\right)\end{array}$ & $\begin{array}{c}\mathrm{P} \\
(\mathrm{mm})\end{array}$ & $\begin{array}{c}\operatorname{Age}_{(2017)} \\
(\text { years })\end{array}$ & $\begin{array}{c}\mathrm{d}_{1.3 \pm} \mathrm{std}_{(2017)} \\
(\mathrm{cm})\end{array}$ \\
\hline L. decidua & Spišsko-gemerský kras & Voniaca valley & 900 & 4.8 & 831 & 50 & $31.8 \pm 3.9$ \\
A. alba & Kremnica mountains & Flochovský back & 950 & 5.8 & 786 & 46 & $33.4 \pm 5.0$ \\
P. abies & Podtatranská kotlina & Tatr. Lomnica & 800 & 5.3 & 833 & 49 & $25.3 \pm 3.5$ \\
P. sylvestris & Spišsko-gemerský kras & Vel'ká Hudrová & 950 & 4.8 & 831 & 37 & $30.7 \pm 3.5$ \\
\hline
\end{tabular}

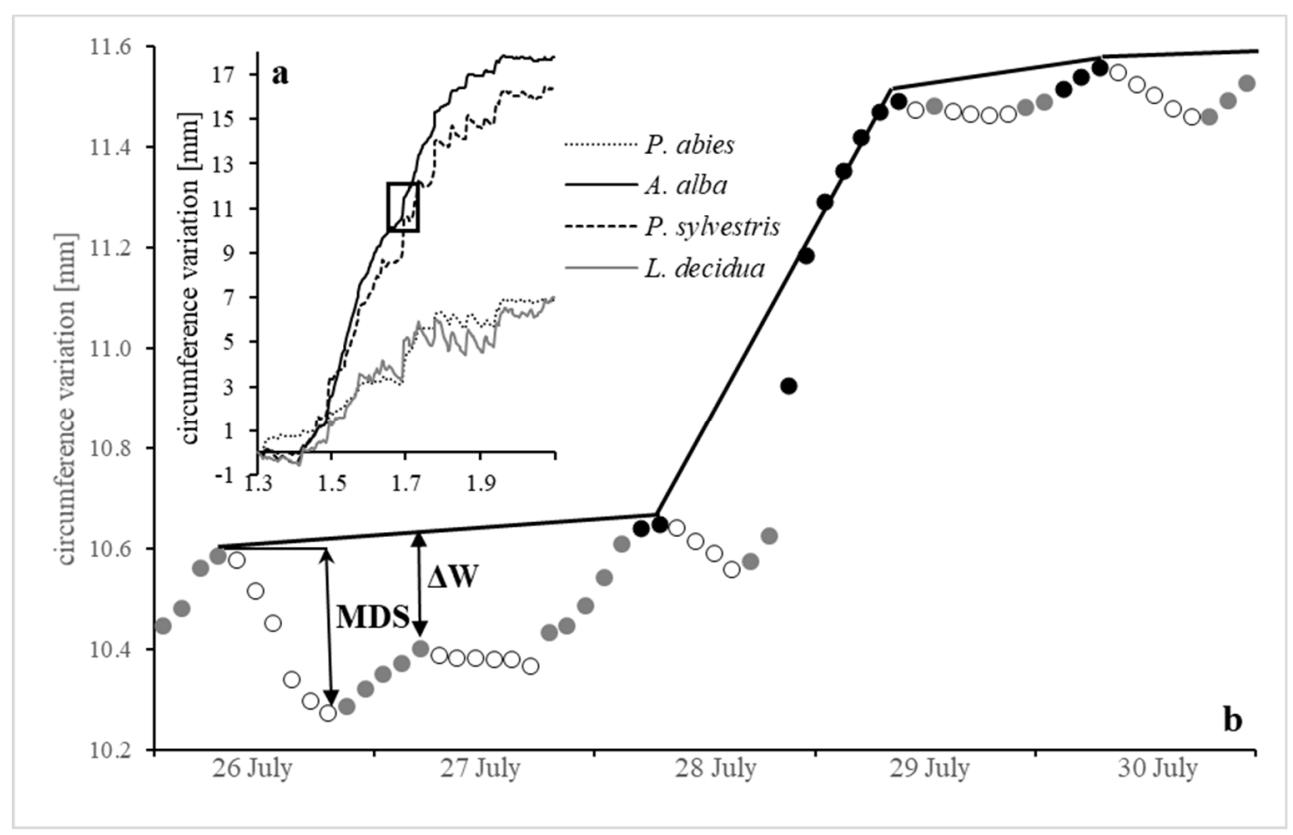

Fig. 1. Seasonal curves of band dendrometer records (BDR) of Abies alba (solid black line), P. sylvestris (dashed black line), P. abies (dotted black line) and L. decidua (solid grey line). Each line represents an average from 5 trees of the same species (a); growth-trend lines (solid black line) and daily stem circumference increase showing distinct phases of a daily stem cycle: contraction (open white circles), expansion (grey circles) and increment (black circles) phase (b).

a moving correlation analysis (MCA), which is based on a progressively shifting period of a fixed number of days across time to compute correlation coefficients (Oberhuber et al., 2015). To provide robust measures of association between environmental variables and $\Delta \mathrm{W}$ and MDS, the length of the calibration window was set to 30 days. Confidence intervals for MCA were analyzed according to Kokfelt and Muscheler (2012)

\section{Periodicity of BDR}

Significant periodicities in the seasonal course of BDR ranging from hours to weeks was identified with a wavelet analysis (Percival and Walden, 2000; Torrence and Compo, 1998). We used the Morlet transformation, which is a sine wave modulated by a classical Gaussian function, establishing a clear distinction between random fluctuations and periodic regions (Torrence and Compo, 1998). Morlet analysis in our study is based on average BDR per species. The generated wavelet spectrum is a time-scale plot, where the $\mathrm{x}$ - and $\mathrm{y}$ axes represent the position along time and periodicity scale, respectively, and the colour contour at each $\mathrm{x} / \mathrm{y}$ point represents the magnitude of the wavelet coefficient at that point. Wavelet analysis was performed using WaveletComp R package (Rösch and Schmidbauer, 2018). We applied a Weibull growth function to BDR series using Statistica 12 (Statsoft). Residuals between the Weibull growth function and BDR were used for periodicity estimation. In Morlet analysis, the lower period was set to $20 \mathrm{~min}$ intervals, while the upper one to $4,600 \mathrm{~min}$ intervals (i.e. 2 months). Shorter periods allow detecting small cycles, while long periods long lasting cycles. To compare and outline diurnal Morlet spectra of different tree species we selected the region from 0.0 to 0.1 to display.

\section{RESULTS AND DISCUSSION \\ Environmental characteristics of the studied periods in 2017 and 2018}

Both study periods from March to October in 2017 and 2018 were characterised by average air temperatures above the longterm normal (1961-1990), while 2018 was the warmer study period with the air temperature by $+2.9^{\circ} \mathrm{C}$ above the long-term average versus $+2.0^{\circ} \mathrm{C}$ in 2017 . Monthly mean air temperatures were in all but one month (March 2018) above their respective long-term normals. The study period in 2018 with the precipitation total of $365 \mathrm{~mm}$ was drier compared to the long-term precipitation normal of $460 \mathrm{~mm}$, while the precipitation total of $533 \mathrm{~mm}$ recorded for the study period in 2017 exceeded the long-term normal by $15 \%$. The precipitation was differently distributed during the study periods. Daily precipitation totals were higher in 2017, while in the year 2018 we recorded a higher number of days without precipitation or with low precip- 
itation (Figures 2c, d). Higher air temperatures and lower precipitation totals in 2018 resulted in higher values of vapour pressure deficit in comparison with 2017 (Figures 2c, d). Overall, variation of vapour pressure deficit was smooth, and the range of 2017 values was slightly greater than of 2018. This was also reflected in the temporal course of soil water potential at all plots (Figures 6,7). At the beginning of both studied periods, soil was sufficiently saturated with water. In May, SWP began to decrease, while in 2018 the reduction in SWP was observed already at the beginning of May in comparison to 2017, when it occurred only in the second half of May. Similarly, the lowest values of $-1.5 \mathrm{MPa}$ were recorded earlier in 2018 than in 2017 (at the end of May versus the beginning of June). Afterwards, SWP values substantially fluctuated depending on the precipitation occurrence, while in 2018 SWP was on average below SWP in 2017 (Figures 6, 7).

\section{Seasonal development of stem growth and tree water status}

Seasonal development of stem circumference records and tree species specific water status characteristics (stem water deficit and maximum daily shrinkage) derived from BDR showed pronounced differences between species and between two monitored periods of the years 2017 and 2018 (Figure 3).
In both years, stem circumference increments of $A$. alba $(17.8 \pm$ $5.3 \mathrm{~mm}$ and $11.2 \pm 4.2 \mathrm{~mm}$, in 2017 and 2018) and P. sylvestris $(16.3 \pm 3.7 \mathrm{~mm}$ and $13.8 \pm 3.1 \mathrm{~mm})$ were more than twice times greater than of $P$. abies $(6.9 \pm 3.5 \mathrm{~mm}$ and $5.3 \pm 2.4 \mathrm{~mm})$ and $L$. decidua $(7.0 \pm 2.1 \mathrm{~mm}$ and $5.2 \pm 1.4 \mathrm{~mm})$. The observed differences in seasonal tree circumference growth result from the existence of species-specific temperature and/or photoperiod thresholds of cambial activity (Begum et al., 2013; Körner and Basler, 2010). Due to more limiting water conditions in 2018 (Figures 2, 7), seasonal radial growth of all tree species in 2018 was reduced in comparison to 2017, while $P$. sylvestris reduced its growth only by $16 \%$ in comparison to other tree species with more than 20\% reduction compared to 2017 (Figures 3a, b). This suggests greater tolerance of $P$. sylvestris to drought (Irvine et al., 1998; Oberhuber et al., 1998). Consistent reduction of radial increment after drought has been observed for multiple species in previous studies (e.g. Camarero et al., 2015).

While in 2017 fir radial increment was the highest, in the subsequent year $P$. sylvestris overtook $A$. alba in radial growth in the second half of July 2018 (Figure 3 b). We assume that this may be caused by the differences in SWP between the plots that were apparent particularly in the second half of 2018 season (Figure 7). While after rainy events in the second half of July, soil at $P$. sylvestris became saturated with water
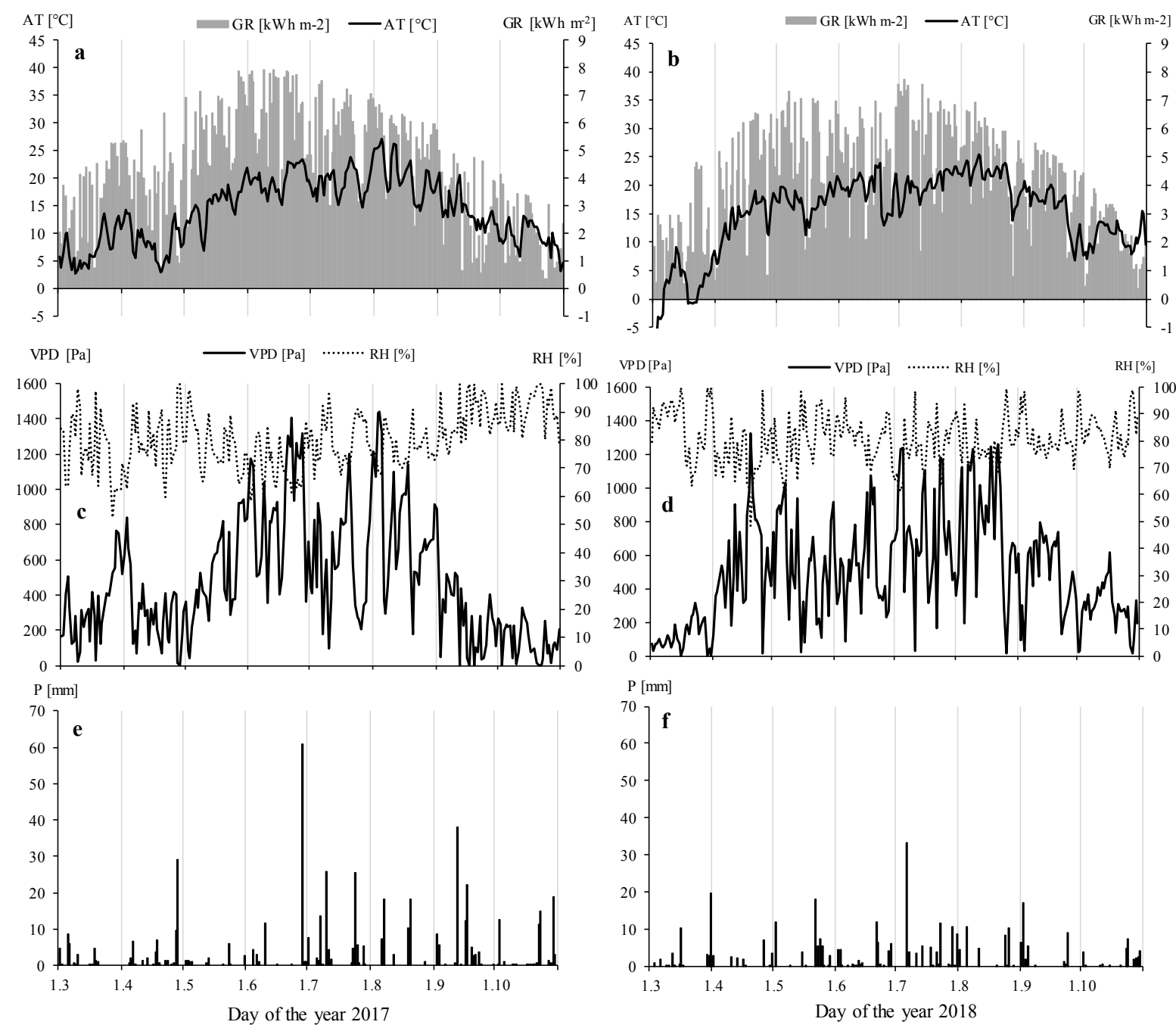

Fig. 2. Courses of daily mean air temperature (AT) and daily totals of global radiation (GR) (a, b), daily mean vapour pressure deficit (VPD) and relative air humidity $(\mathrm{RH})(\mathrm{b}, \mathrm{d})$ and daily precipitation totals $(\mathrm{P})(\mathrm{e}, \mathrm{f})$ recorded during the study periods (March-October) in 2017 and 2018. 

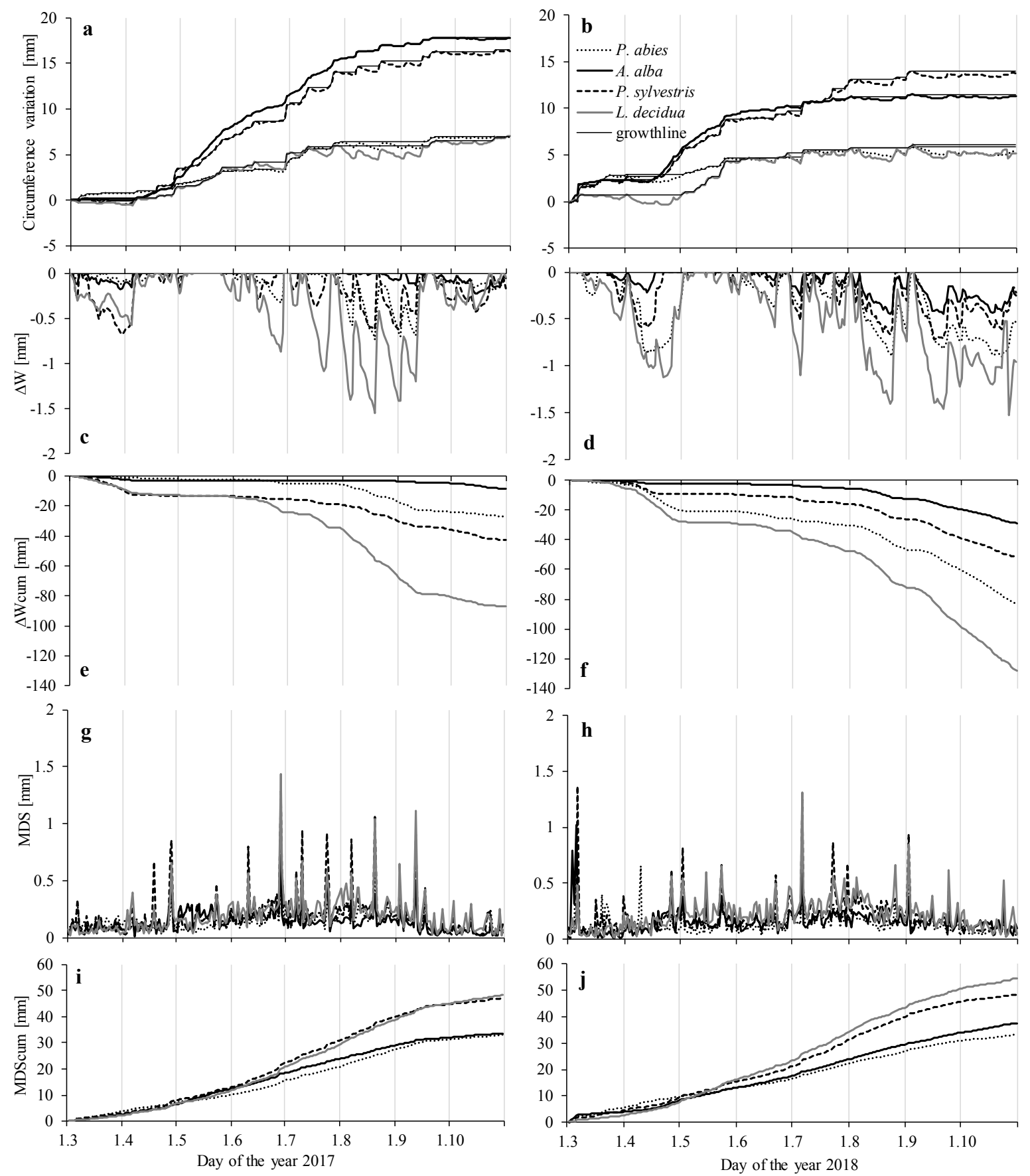

Fig. 3. Growth line (solid thin line) and band dendrometer records (BDR) of stem circumference over bark (a, b), mean daily stem water deficit $(\Delta \mathrm{W})(\mathrm{c}, \mathrm{d})$ and cumulative stem water deficit $\left(\Delta \mathrm{W}_{\text {cum }}\right)(\mathrm{e}, \mathrm{f})$, maximum daily shrinkage (MDS) $(\mathrm{g}, \mathrm{h})$ and cumulative maximum daily shrinkage $\left(\mathrm{MDS}_{\mathrm{cum}}\right)(\mathrm{i}, \mathrm{j})$.

$(\mathrm{SWP}=0.0 \mathrm{MPa}), \mathrm{SWP}$ values at other plots were reduced to $-0.5 \mathrm{MPa}$ already at the end of April or beginning of May 2018 and remained below this threshold until the end of the observation period (Figure 7). Soil water conditions at $A$. alba plot were most limiting, due to which the radial growth of this species stagnated (Figure 3b). BDR of all species showed temporal fluctuations in stem circumference with plateaus representing stagnation periods. The largest fluctuations in BDR were recorded for L. decidua due to its anisohydric strategy (Bréda et al., 2006). Notable stagnation of radial growth occurred in periods with low precipitation and soil water deficit (Figures 2, 6 and 7). Stem circumference increase was clearly observed after precipitation events, which indicates re-hydratation of "water storage cells" (Vieira et al., 2013; Zweifel et al., 2005).
Indirect measures of tree water status (MDS and $\Delta \mathrm{W}$ ) are very valuable for detecting physiological responses to water deficits (Oberhuber et al., 2015; Zweifel et al., 2005). Extracted water deficit values indicate limited water storage relative to fully hydrated stem conditions. Increasingly negative values mean more pronounced water shortage. Over the examined periods, stem water deficit gradually decreased in all species, although with different magnitudes (Figures 3c, d). This trend was occasionally disrupted by precipitation events, after which $\Delta \mathrm{W}$ reached values close to zero (Figure 2, Figures $3 \mathrm{c}, \mathrm{d}$ ). Calculated $\Delta \mathrm{W}$ and MDS of all species showed synchronous fluctuations in both years (Figures 3c-f). L. decidua showed greatest cumulative stem water deficit $(-86.9 \pm 47.6 \mathrm{~mm}$ in 2017 , and $-128.4 \pm 48.1 \mathrm{~mm}$ ) and seasonal daily $\Delta \mathrm{W}$ throughout 

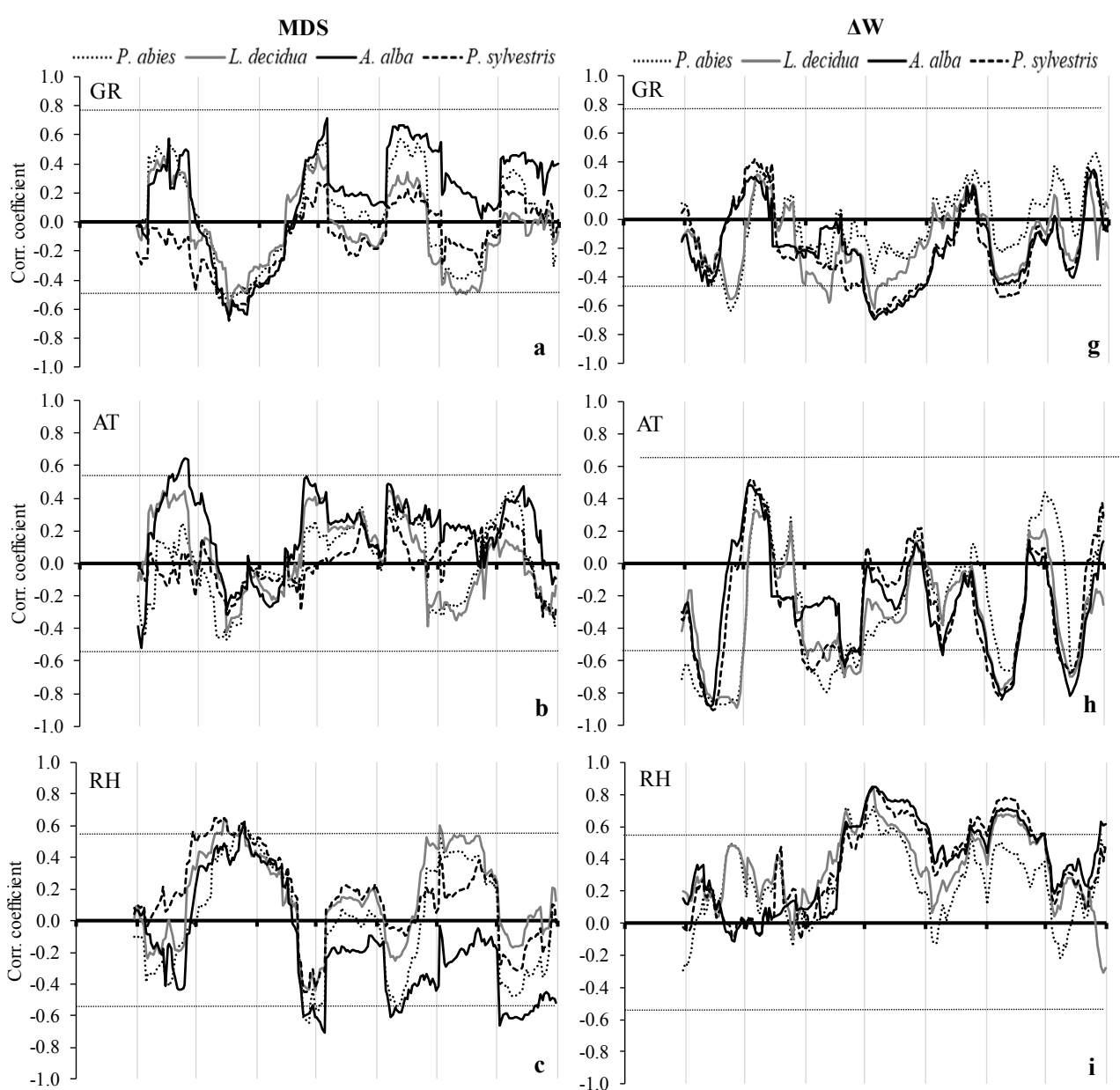

Fig. 4. Species-specific moving correlations (windows of 30 days) between environmental variables: global radiation (GR), air temperature (AT), relative air humidity (RH), vapour pressure deficit (VPD), precipitation (P) and soil water potential (SWP) and tree water status characteristics: maximum daily stem shrinkage (MDS) $(\mathrm{a}-\mathrm{f})$ and tree water deficit $(\Delta \mathrm{W})(\mathrm{g}-\mathrm{l})$ of four tree species: A. alba (solid black line), $P$. abies (dotted black line), $P$. sylvestris (dashed black line) and L. decidua (solid grey line) during the study period of the year 2017.
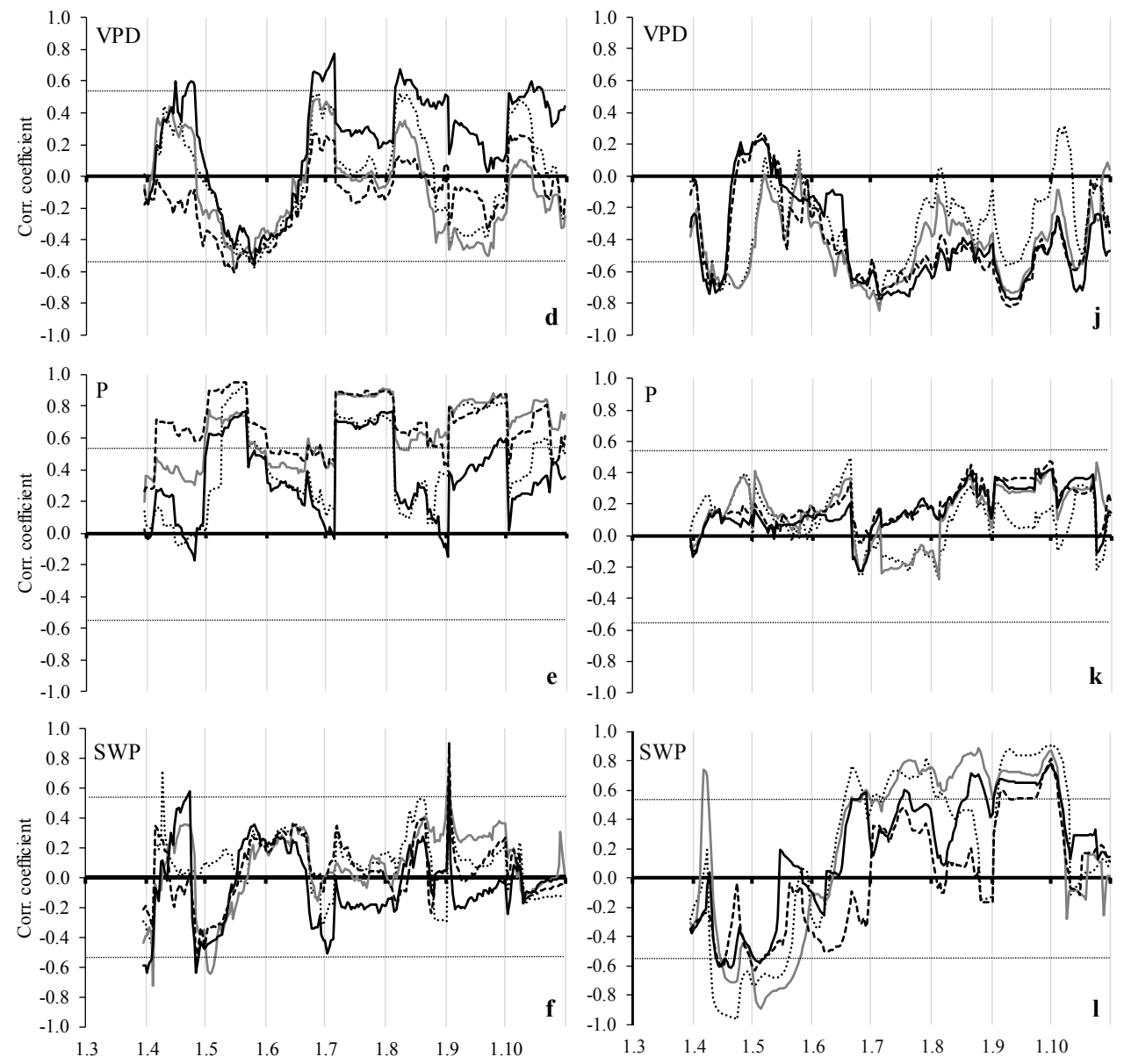

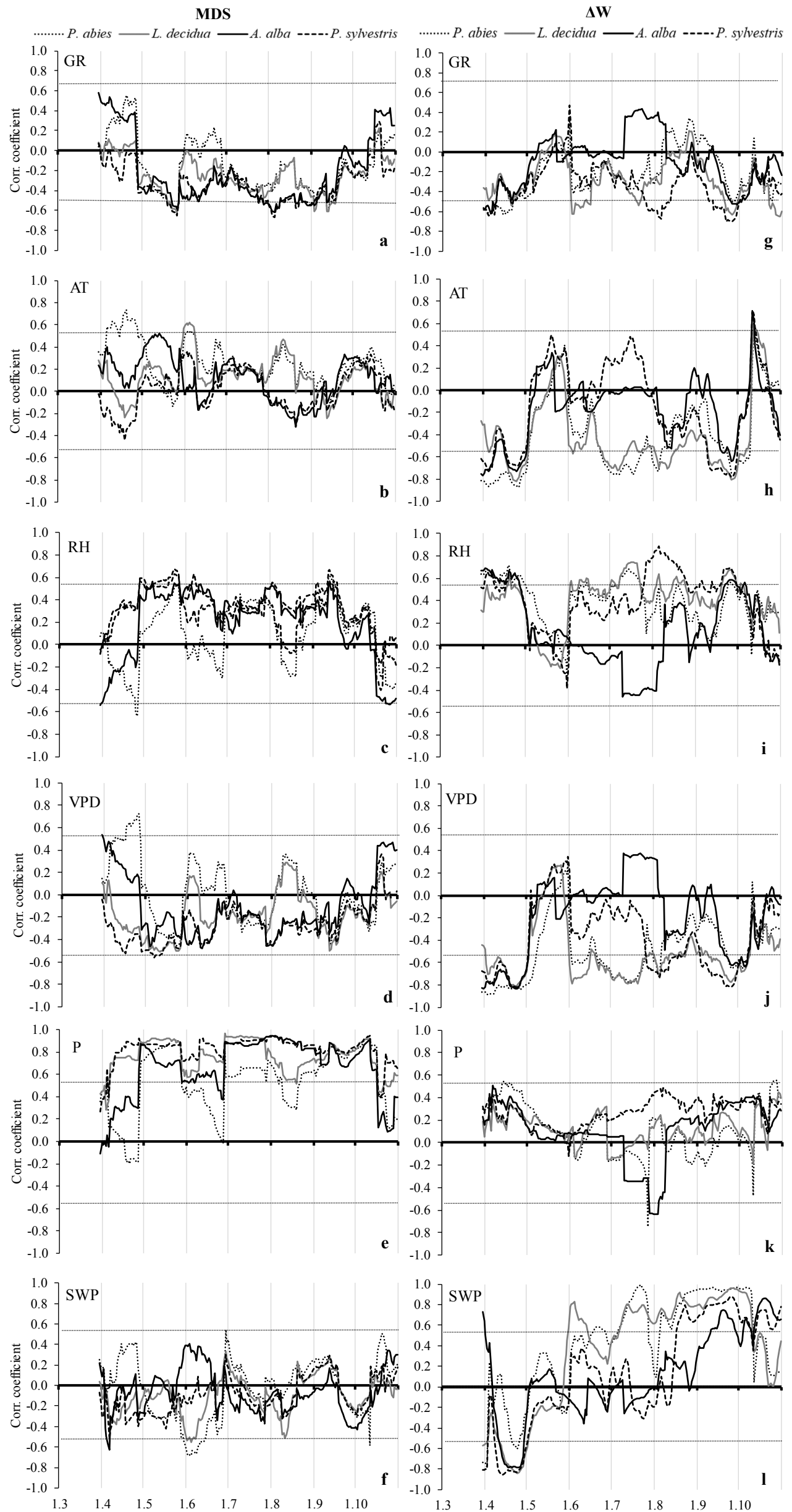

Fig. 5. Species-specific moving correlations (windows of 30 days) between environmental variables: global radiation (GR), air temperature (AT), relative air humidity $(\mathrm{RH})$, vapour pressure deficit (VPD), precipitation (P) and soil water potential (SWP) and tree water status characteristics: maximum daily stem shrinkage (MDS) $(\mathrm{a}-\mathrm{f})$ and tree water deficit $(\Delta \mathrm{W})(\mathrm{g}-1)$ of four tree species: A. alba (solid black line), $P$. abies (dotted black line), P. sylvestris (dashed black line) and L. decidua (solid grey line) during the study period of the year 2018 . 
a) $P$. abies
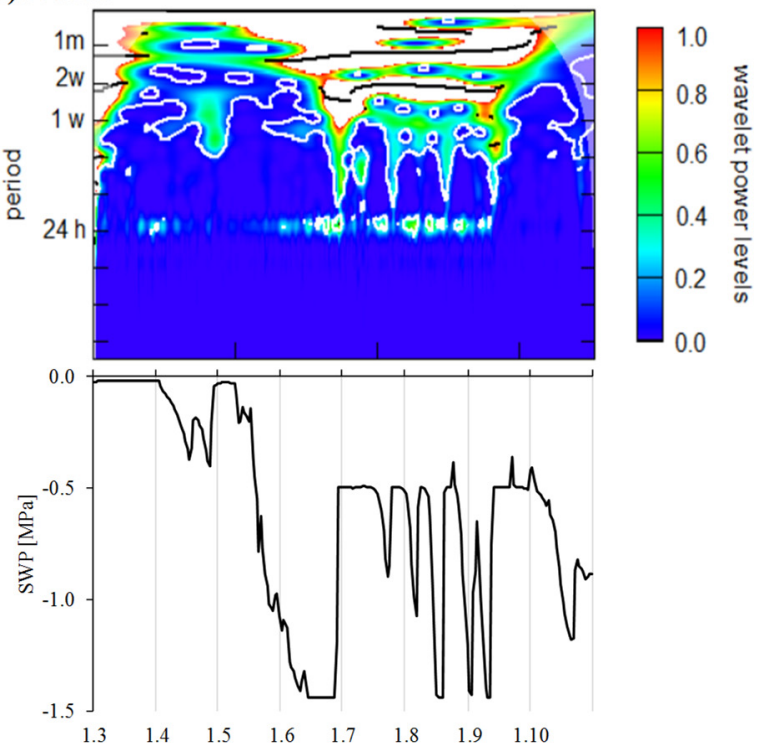

c) P. sylvestris
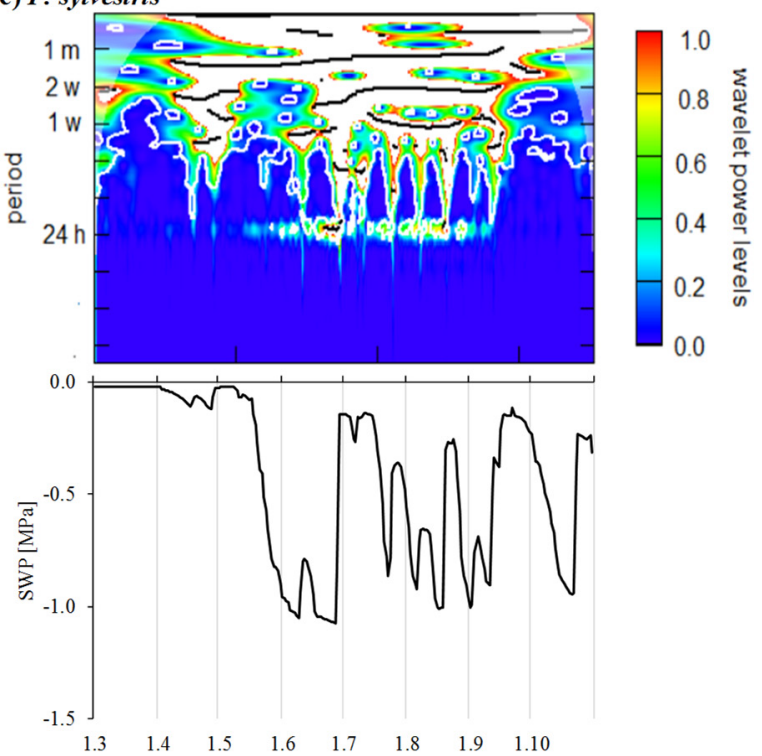

b) A. alba
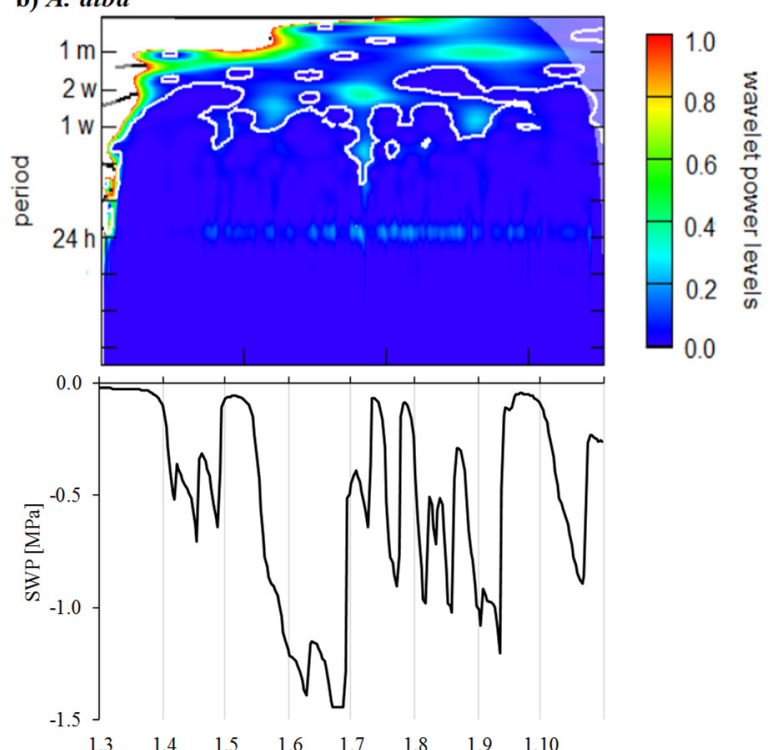

d) L. decidua
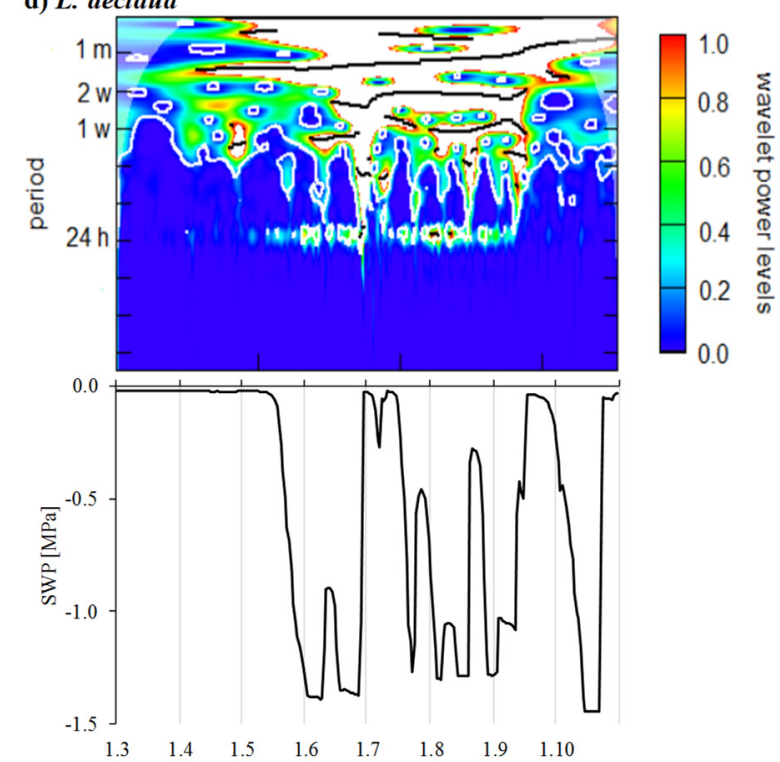

Fig. 6. Morlet wavelet spectra of 20-min measured records of stem circumference and soil water potential for the studied tree species: $P$. abies (a), A. alba (b), P. sylvestris (c) and L. decidua (d) in the study period (March-October) of the year 2017. Dark red and white colours are assigned to the highest wavelet power spectra, whereas a dark blue colour is assigned to the lowest values. Wavelet power levels were set from 0.0 to $1.10^{-1}$.

both study years because, unlike the other three investigated species, larch maintains high transpiration rates even under dry conditions (Bréda et al., 2006). On the contrary, the smallest values of cumulative and daily $\Delta \mathrm{W}$ were determined for $A$. alba throughout both study years, since this species is known for its strong regulation of transpiration (Nourtier et al., 2014).

However, when we examined relative changes in stem water deficit of the same species between the years, we found that cumulative $\Delta \mathrm{W}$ of $A$. alba in 2018 was 3.31 times greater than in $2017(-28.8 \pm 16.6 \mathrm{~mm}$ versus $-8.7 \pm 2.0 \mathrm{~mm})$. Although this relative increase was the largest from all investigated species, cumulative $\Delta \mathrm{W}$ of $A$. alba remained the lowest of all species (Figures 3e, f). Similar threefold increase in cumulative stem water deficit was observed for P. abies $(-27.2 \pm 11.3 \mathrm{~mm}$ in 2017 versus $-83.2 \pm 31.2 \mathrm{~mm}$ in 2018). In 2017, cumulative $\Delta \mathrm{W}$ of $P$. abies was lower in comparison to $P$. sylvestris, while in 2018 it was the other way round, because $P$. sylvestris increased its cumulative stem water deficit only by $20 \%(-42.8 \pm 19.5 \mathrm{~mm}$ in 2017 and $-51.5 \pm 15.3 \mathrm{~mm}$ in 2018). Similar increase of smaller magnitude in cumulative $\Delta \mathrm{W}$ by less than $50 \%$ was observed for $L$. decidua in 2018 . We assume that the lower interannual changes in cumulative $\Delta \mathrm{W}$ of $P$. sylvestris and $L$. decidua result from lower elasticity of their tissues due to their higher wood density (Požgaj et al., 1993; Zeidler et al., 2018).

González-Rodríguez et al. (2017) have shown that stem diameter shrinkage is mainly determined by sap flow changes. Variations in stem diameter act in response to a tree daily water intake and loss of moisture (Irvine and Grace, 1997). In both studied years, species specific maximum daily shrinkage and seasonal cumulative shrinkage were greater for L. decidua and $P$. sylvestris than for $P$. abies and $A$. alba (Figures $3 \mathrm{i}, \mathrm{j}$ ). This indicates species specific water status regulation driven by bark thickness (Mencuccini et al., 2013). Oberhuber et al. (2014) showed that the fraction of reversible stem swelling and shrinkage caused by diurnal changes in atmospheric conditions is higher when trees are growing slowly as is L. decidua. The 
a) $P$. abies
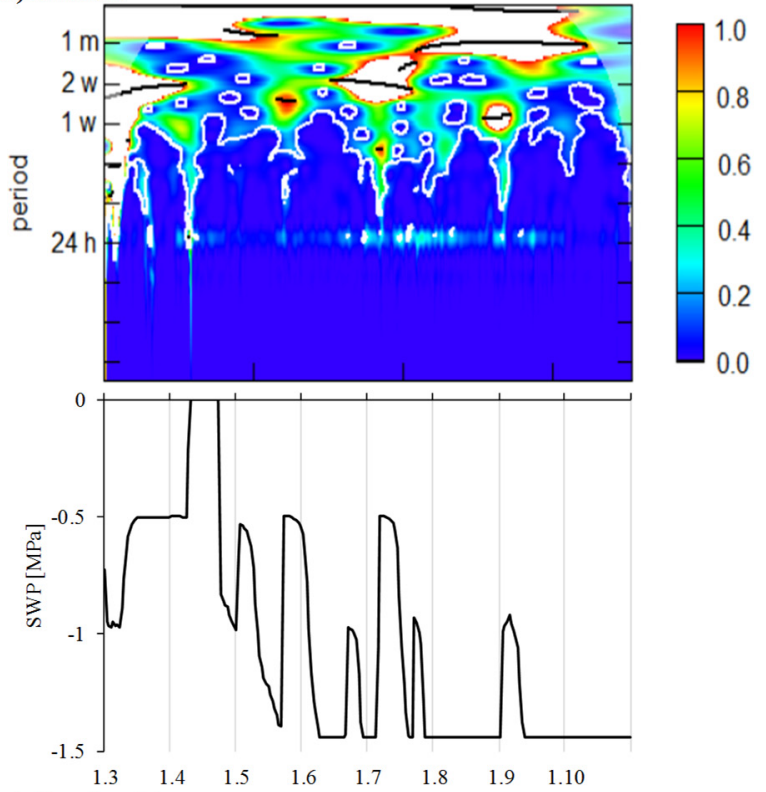

c) P. sylvestris
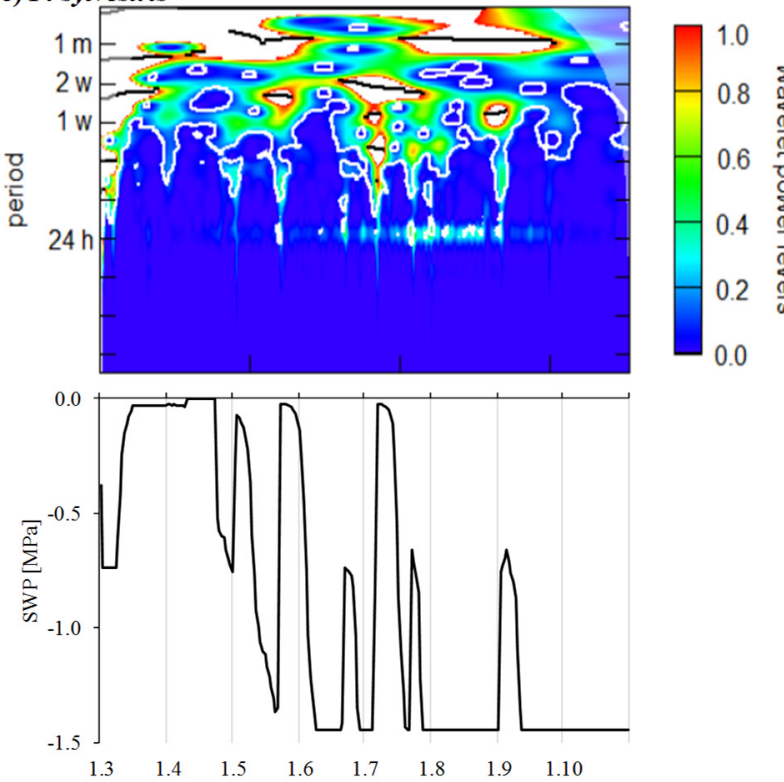

b) A. alba
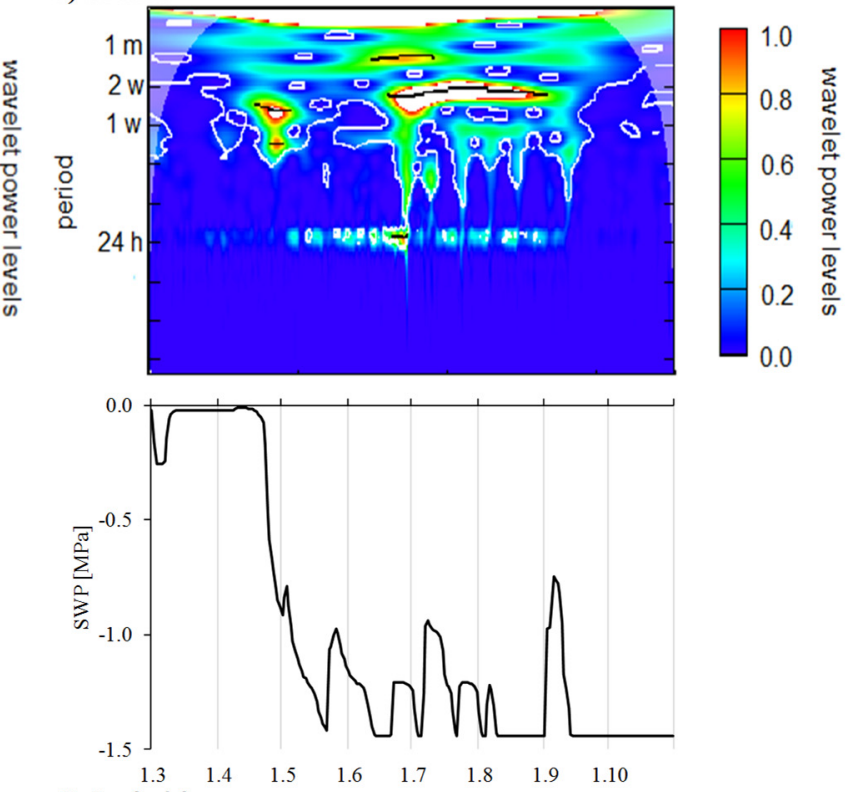

d) L. decidua
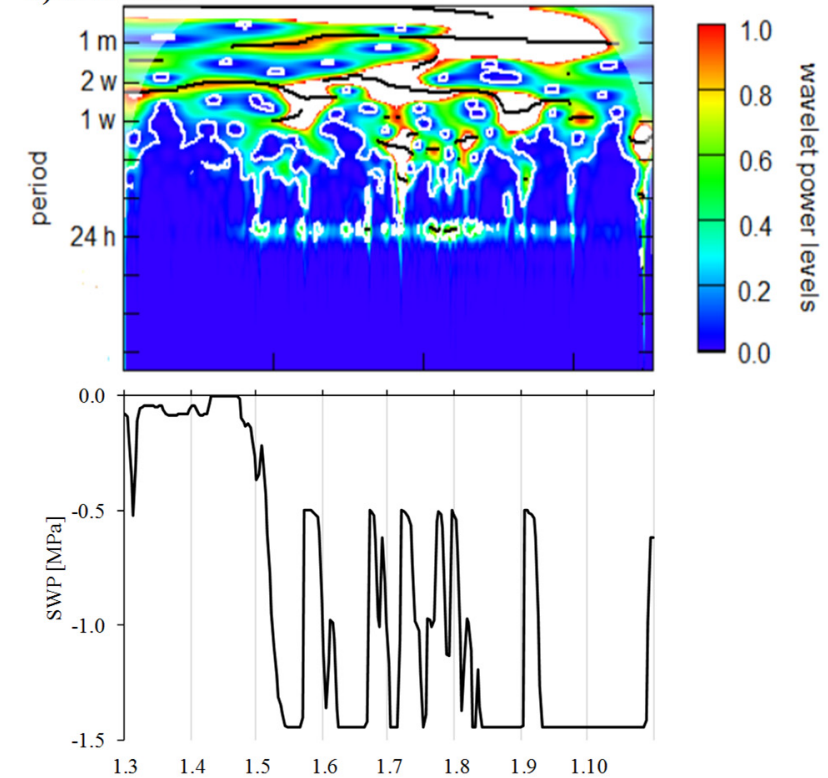

Fig. 7. Morlet wavelet spectra of 20-min measured records of stem circumference and soil water potential for the studied tree species: $P$. abies (a), A. alba (b), P. sylvestris (c) and L. decidua (d) in the study period (March-October) of the year 2018. Dark red and white colours are assigned to the highest wavelet power spectra, whereas a dark blue colour is assigned to the lowest values. Wavelet power levels were set from 0.0 to $1.10^{-1}$.

seasonal cumulative shrinkage of the species in the years 2017 and 2018 increased in the following order: P. abies $(35.1 \pm 14.7$ $\mathrm{mm}, 34.9 \pm 12.8 \mathrm{~mm})$, A. alba $(35.0 \pm 11.8 \mathrm{~mm}, 39.2 \pm 13.3$ $\mathrm{mm})$, P. sylvestris $(45.7 \pm 6.3 \mathrm{~mm}, 51.1 \pm 7.9 \mathrm{~mm})$ and $L$. decidua $(49.6 \pm 14.6 \mathrm{~mm}, 56.8 \pm 12.7 \mathrm{~mm})$. MDS has been shown to gradually decline when trees are experiencing poor water supply for extended periods of time (Dietrich et al., 2018). Declining MDS with declining soil water supply is caused by insufficient tissue rehydration during night time, due to which the stem undergoes a constant shrinkage (on a daily cadence) during dry periods. Since MDS is proportional to the volume of daily used storage water (Zweifel et al., 2000), poor night-time rehydration, and, therefore, declining storage water, will have a decreasing effect on MDS during dry periods (Dietrich et al., 2018).

\section{Environmental conditions and tree water status}

Tree growth and water status are controlled by a vast array of conditions. Several authors (e.g. Köcher et al., 2013, Oberhuber et al., 2015) reported that $\Delta \mathrm{W}$ and MDS are closely related to drought stress and are mainly determined by a combination of atmospheric and soil conditions. The close lateral linkage of water conducting xylem with phloem translates changes in tree water status directly to shrinking and swelling of nonlignified tissues in the bark and phloem (Zweifel and Häsler, 2001). Spearman rank-correlations between tree water status characteristics (MDS and $\Delta \mathrm{W}$ ) and environmental variables (Table 2) revealed that all monitored environmental characteristics were highly significantly correlated with MDS irrespective of species. Closest positive correlations of MDS were found 
with GR and AT of all species. Significant negative relationships were observed with RH and SWP. Hence, close correlations found between daily radial change and VPD, which reflects RH and air temperature and influences transpiration rate besides wind and radiation, can be attributed to changes in leaf transpiration. Transpiration, in turn, will directly cause water depletion of the bark storage compartments and, thus, stem shrinkage. Further, stomatal regulation strongly determines tree water relations and thus has a distinct impact on $\Delta \mathrm{W}$ (Zweifel et al., 2001). SWP affected MDS of $P$. sylvestris and $L$. decidua more strongly than $\Delta \mathrm{W}$ of $P$. abies. This result most likely indicates that in the short term the use of water stored in the living stem tissues makes $P$. abies less dependent on the current water availability in the soil. Strongest relationships were found between MDS and air temperature $(\mathrm{P}<0.001)$ with the highest correlation coefficient for $L$. decidua $(\mathrm{r}=0.676)$, while $\Delta \mathrm{W}$ was most strongly correlated to SWP (Table 2). Closer correlations between MDS and atmospheric conditions than with soil water status indicate that trees utilise water stored in stem reservoirs for transpiration, which is driven by climate variables (Ehrenberger et al., 2012; Zweifel et al., 2005), on a daily basis. In contrast to MDS, $\Delta \mathrm{W}$ allows accounting for accumulated water deficits also over extended periods (few days to months) of drought. Differences between these two variables only become apparent during longer periods of stem shrinkage. Hence, elastic tissue reservoirs contribute to the avoidance of the early stomatal regulation under increasing soil drought (Čermák et al., 2007). Soil moisture, influenced by changing precipitation, is a slowly changing factor, the effects of which can only be seen over longer time scales. Atmospheric moisture, on the other hand, changes on a daily scale, and through its effect on transpiration it hereby directly influences stem diameter variation. Because a close coupling of transpiration with xylem sap flow was reported by Steppe et al. (2006), missing significant relationships between SWP and tree water parameters extracted from BDR of all species imply that transpiration draws upon water stored in the stem rather than soil water (Betsch et al., 2011; Čermák et al., 2007). This reasoning is supported by Zweifel et al. (2005), who found that transpired water is more strongly withdrawn from internal storage tissues at dry sites than at moist sites. Replenishment of these water reservoirs strongly depends on available water in soil (Turcotte et al., 2011), due to which tree water deficit is more affected by SWP. Our results contradict to Oberhuber et al. (2015), who found that $\Delta \mathrm{W}$ was controlled more by air temperature. We assume that this is because their study dealt with drier soil conditions than our study, under which atmospheric conditions may become more prevailing influential factors, since soil water is already limiting (Hinckley et al., 1978; Pataki et al., 1998). All species had the highest significant linear negative relationships between soil water potential and MDS and high positive relationships of SWP with $\Delta \mathrm{W}$. The highest positive value of correlation coefficient between soil water potential and $\Delta \mathrm{W}$ was found for $P$. abies $(\mathrm{r}=0.505)$ and the lowest value was found for $P$. sylvestris $(\mathrm{r}=0.216)$. Lower although significant values of correlation coefficients were found between tree water status characteristics and relative air humidity and precipitation in all species. Global radiation and $\Delta \mathrm{W}$ positively significantly correlated only in the case of shade tolerant $A$. alba $(\mathrm{r}=0.243)$ (Table 2). Its lowest correlation coefficients between $\Delta \mathrm{W}$ and AT, $\mathrm{RH}$, and VPD from all investigated species confirm its high capability to regulate transpiration (Aussenac, 2002).

Moving correlation analysis with 30-day windows showed the closest positive correlations of MDS with precipitation (Figures 4, 5e) in all monitored species in both years. Trees undergo daily cycles of circumference fluctuation that are usually consistent with expectations based on known physiological mechanisms (Steppe et al. 2015), and they commonly exhibit circumference changes in response to precipitation events (Figures $3,4 \mathrm{e}, 5 \mathrm{e}) . \Delta \mathrm{W}$ showed significant negative correlations with soil water potential in April and significant positive correlations with SWP from June to October. In both study periods, $L$. decidua and $P$. abies reached the highest values of correlation coefficients between $\Delta \mathrm{W}$ and SWP (Figures 5, 61). High significant negative correlations between AT, VPD and $\Delta \mathrm{W}$ of L. decidua and P. abies were observed in July and September in the year 2017. Correlations revealed close negative relationships between $\Delta \mathrm{W}$ and AT in April, June and in September and October and between $\Delta \mathrm{W}$ and VPD in April, June, July and September in the year 2018 irrespective of species. The results did not reveal any significant correlations between $\Delta \mathrm{W}$ and precipitation in either of the study periods (Figures $4,5 \mathrm{k}$ ). As depicted in Figures 4 and 5, MDS and $\Delta \mathrm{W}$ of all species showed more synchronous response to environmental factors in the year 2018 in comparison with 2017. Between the beginning of June and September in the year 2017 we observed asynchronous reactions of species $\Delta \mathrm{W}$ to environmental factors (Figures $4,5 \mathrm{~g}-1)$. MDS was most frequently significantly correlated with precipitation, while greater fluctuations were observed in 2018 (Figures $4 \mathrm{~d}$ and $5 \mathrm{~d}$ ). Higher correlations of MDS with precipitation were found for $P$. sylvestris and $L$. decidua due to greater thickness of bark. High temperatures stimulate evaporation rates, due to which water availability, characterised by soil water potential, becomes further constrained. This agrees with other studies from temperate forests at low elevations that reported that above average temperatures induce negative growth responses (Battipaglia et al., 2009; Schuster and Oberhuber, 2013). High sensitivity of stem water status to VPD and soil moisture was reported in several experimental studies (e.g. Turcotte et al., 2011; Will et al., 2013).

Our results support reports presenting $A$. alba more resilient to climate change than other conifers of temperate forests (Bouriaud and Popa, 2009; Latreille et al., 2017) and an adaptive species to changing conditions (Bošel'a et al., 2018) including adverse events such as drought (Vitali, 2017). Since its productivity does not seem to be affected by increasing temperature (Bošel'a et al., 2018; Usoltsev et al., 2019), A. alba is often considered as a prospective species under climate change (Lindner et al., 2008). In another study of the 2003 drought event, $P$. abies cell production stopped in August to September of the drought year, while A. alba was active until October (Gričar and Čufar, 2008). At similar elevations in Slovenian forests, A. alba had a significantly longer wood formation period than spruce, with the beginning in early April and the end in late October (Gričar and Čfar, 2008). It appears that longer periods of wood formation in $A$. alba allow this species to partially compensate for drought periods during which cell formation ceases. This may be achieved through early or late growth during dry years, and through replenishing resources to support growth in the following year, resulting in its higher resistance and resilience. The fact that $P$. sylvestris was a less responsive species than $P$. abies and $L$. decidua was expected because this species is known to be drought-resistant maintaining a tight control over its transpiration (Oberhuber et al., 1998) already in early stages of drought (Irvine et al., 1998). Pronounced stomatal control generally allows high drought avoidance capacity (Aubin et al., 2016). Moreover, P. sylvestris is known to be well protected against drought due to its imbedded stomata and pronounced waxy layer on the epidermis (Krakau et al., 2013). Limited radial growth of $L$. decidua at the studied 
Table 2. Species-specific Spearman rank-correlation coefficients (r) for the relationships between daily environmental variables: global radiation (GR), air temperature (AT), relative air humidity $(\mathrm{RH})$, precipitation $(\mathrm{P})$, vapour pressure deficit (VPD) and soil water potential (SWP), and tree water status characteristics: maximum daily shrinkage (MDS) and tree water deficit $(\Delta \mathrm{W})$ in the study periods of the years 2017 and 2018

\begin{tabular}{|c|c|c|c|c|c|c|c|}
\hline & & GR & AT & RH & $\mathrm{P}$ & VPD & SWP \\
\hline \multirow{2}{*}{ P. abies } & MDS & $0.334 * * *$ & $0.418 * * *$ & $-0.269 * * *$ & $0.090 *$ & $0.366^{* * *}$ & -0.073 \\
\hline & $\Delta \mathrm{W}$ & 0.069 & $-0.183^{* * *}$ & $0.132 * *$ & $0.150 * * *$ & $-0.220 * * *$ & $0.505^{* * *}$ \\
\hline \multirow{2}{*}{ P. sylvestris } & MDS & $0.397 * * *$ & $0.611 * * *$ & $-0.157 * * *$ & $0.219 * * *$ & $0.394 * * *$ & $-0.256 * * *$ \\
\hline & $\Delta \mathrm{W}$ & 0.059 & -0.026 & $0.210 * * *$ & $0.261 * * *$ & $-0.195 * * *$ & $0.216^{* * *}$ \\
\hline \multirow{2}{*}{ L. decidua } & MDS & $0.432 * * *$ & $0.676^{* * *}$ & $-0.092 *$ & $0.220 * * *$ & $0.408 * * *$ & $-0.345^{* * *}$ \\
\hline & $\Delta \mathrm{W}$ & -0.052 & $-0.254 * * *$ & $0.268^{* * *}$ & $0.221 * * *$ & $-0.351 * * *$ & $0.401 * * *$ \\
\hline \multirow{2}{*}{ A. alba } & MDS & $0.446 * * *$ & $0.543 * * *$ & $-0.273 * * *$ & 0.073 & $0.470 * * *$ & $-0.408 * * *$ \\
\hline & $\Delta \mathrm{W}$ & $0.243 * * *$ & $0.099 *$ & 0.042 & $0.176^{* * *}$ & -0.002 & $0.298^{* * *}$ \\
\hline
\end{tabular}

site (Figures 3a, b) is a consequence of its sensitivity to soil water conditions (Eilmann and Rigling, 2012), especially during summer months. Its weak adjustability to drought results from its deciduous habit and/or anisohydric strategy resulting in high transpiration rates under drought, and finally causing impairment of tree water status (Bréda et al., 2006; Oberhuber et al., 2015). Isohydric species such as $P$. abies, $P$. sylvestris or $A$. alba suffer more but recover quicker under short drought events, while anisohydric species such as larch reduce their growth less but may suffer during longer lasting drought events (Hartmann, 2011; McDowell et al., 2008).

Morlet wavelet analysis of the detrended BDR of four coniferous species confirmed the occurrence of periodicity in BDR with various frequency ranging from days to weeks in both studied years. Significant daily cycles $(\mathrm{p}<0.05)$ were found during substantial parts of both years 2017 and 2018, except for $A$. alba in the year 2017 . The daily cycle was notably more pronounced during the rainless periods (Figures 6, 7, Figures 3 $\mathrm{e}, \mathrm{f})$ reflecting the changing plant hydric status during a day (Ježík et al., 2016; Zweifel et al., 2006). Pronounced occurrence of daily cycles in the wavelet spectrum of $P$. abies, $L$. decidua and A. alba in our study in the warmer and drier year 2018 (Figure 2) is connected with plant water reservoir depletion under more stressing conditions (Oberhuber et al., 2015). $P$. sylvestris exhibited the presence of diurnal cycles in more favourable conditions of the year 2017. This result can be explained by $P$. sylvestris elasticity of bark affected by atmospheric conditions (Oberhuber et al., 2020). In the year 2017 characterised with greater short-term fluctuations of soil water conditions (Figure 6), both A. alba and P. sylvestris grew in a cascade-like manner, while in the year 2018 they adapted to limited soil water conditions due to which the daily cycle was not so pronounced (Figure 7). Since the presented hypothesis is based only on two study periods, a more extensive study is required for its verification. To our knowledge, the literature about species specific wavelet spectra response to hydric conditions is rather scarce.

Morlet wavelet analysis offered us an opportunity to present tree water status from a different point of view that stem water status indicators (MDS and $\Delta \mathrm{W}$ ) usually provide. Relations between the diurnal water status indicator (MDS) and environmental predictors (SWP) were relatively low. We speculate this was due to more frequent low MDS amplitudes in rainless periods when compared with MDS peaks just after rain events resulting in low Spearman correlation values. Since Morlet analysis incorporates also low MDS amplitudes in resulting power spectra, Morlet spectra showed synchronous courses with SWP (Figures 6,7) despite the low correlation between SWP and MDS (Figures 4, 5).
The advantage of Morlet analysis is that it visualizes also BDR cycles of other than of a diurnal length (Oberhuber et al., 2015) driven by underlying processes such as cell division and enlargement, phenology, etc. (Rathgeber et al., 2016). No BDR cycles appeared at a sub-diurnal scale (Figures 6 and 7). However, we revealed evident occurrence of significant 1-2 weeklong cycles corresponding to highly negative SWP values. A thorough analysis of these long-lasting cycles is beyond the scope of this paper since it requires additional data on e.g. phenological development and respective statistical testing.

\section{CONCLUSIONS}

Knowledge on the relationships between climate and growth is essential for assessing the future performance of conifers exposed to drought and air temperature anomalies. Detailed information on climate-growth relationships can be obtained via dendroecological analyses. Fine-scale stem circumference dynamics recorded by dendrometers reflect tree water status and hold some potential for characterising forest ecophysiology. This is one of the few studies that compared tree growth responses of economically important coniferous species of Central Europe (P. sylvestris, P. abies, A. alba and L. decidua) growing at the same site characterised by warmer and drier environmental conditions in comparison to their natural habitats. Thus, the settings of the study gave us an opportunity to examine tree species response to projected future climate.

Monitored species exhibited remarkably different growth patterns over two climatically different periods in 2017 and 2018. The differences in drought responses between the species may be explained by their intrinsic differences in morphology and physiology. L. decidua and P. abies were more sensitive species to environmental conditions than $A$. alba and $P$. sylvestris that was reflected in their radial stem growth. A. alba exhibited smooth radial growth during the growing season unaffected by the changes in environmental conditions including periodical droughts. Climate-growth relationships revealed competitive advantage of drought adapted $P$. sylvestris compared to $P$. abies and L. decidua. During the drought in 2018, $P$. sylvetris overtook $A$. alba in stem radial growth, which indicates that although $A$. alba can withstand slight temperature increase, it becomes less resistant than $P$. sylvestris if higher temperature is combined with water deficit. Although our study did not examine population-level responses, it clearly indicates that Silver fir is more resistant and resilient to drought events, and therefore, it is a suitable alternative to P. abies or L. decidua.

The examined tree water status parameters, namely stem water deficit and maximum daily shrinkage, were proved suitable for the comparison of different tree species water status. Tree 
water status parameters ( $\Delta \mathrm{W}$ and MDS) should be used for the inter-species comparison of water status with regard to different bark thickness of tree species and its corresponding elasticity, which can significantly affect the derived water status signal. Moving correlation analysis showed that stem water deficit of $L$. decidua and $P$. abies was more sensitive to air temperature and VPD than $A$. alba and $P$. sylvestris. During summer months, precipitation deficits, heat waves and consequently decreased soil water potential significantly affected stem circumference increase and tree water deficit, mainly of $L$. decid$u a$ and $P$. abies, also given that the studied species are not situated in an area of their optimal species growth.

Acknowledgements. The study was supported by research grants of the Slovak Research and Development Agency APVV-160325, APVV-16-0306, APVV-17-0644, APVV-15-0265, APVV-18-0390 and the Scientific Grant Agency of the Ministry of Education, Science, Research and Sport of the Slovak Republic under contracts VEGA 2/0049/18. This work was also supported by the grant "EVA4.0", No. CZ.02.1.01/0.0/0.0/16_019/0000803 financed by the OP RDE.

\section{REFERENCES}

Allen, C.D., Breshears, D.D., McDowell, N.G., 2015. On underestimation of global vulnerability to tree mortality and forest die-off from hotter drought in the Anthropocene. Ecosphere, 6, 8, Article Number 129.

Aubin, I., Munson, A.D., Cardou, F., Burton, P.J., Isabel, N., Pedlar, J.H., et al., 2016. Traits to stay, traits to move: are view of functional traits to assess sensitivity and adaptive capacity of temperature and boreal trees to climate change. Environ. Rev., 24, 164-186.

Aussenac, G., 2002. Ecology and ecophysiology of circummediterranean firs in the context of climate change. Ann. For. Sci., 59, 823-832.

Battipaglia, G., Saurer, M., Cherubini, P., Siegwolf, R.T.W., Cotrufo, M.F., 2009. Tree rings indicate different drought resistance of a native (Abies alba Mill.) and a non-native (Picea abies (L.) Karst.) species co-occurring at a dry site in Southern Italy. For. Ecol. Manag., 257, 820-828.

Begum, S., Nakaba, S., Yamagishi, Y., Oribe, Y., Funada, R., 2013. Regulation of cambial activity in relation to environmental conditions: understanding the role of temperature in wood formation of trees. Physiol. Plant., 147, 46-54.

Betsch, P., Bonal, D., Breda, N., Montpied, P., Peiffer, M., Tuzet, A., Granier, A., 2011. Drought effects on water relations in beech: the contribution of exchangeable water reservoirs. Agric. For. Meteorol., 151, 531-543.

Bolte, A., Ammer, C., Löf, M., Nabuurs, G.J., Schall, P., Spathelf, P., Rock, J., 2009. Adaptive forest management in central Europe: climate change impacts, strategies and integrative concept. Scand. J. For. Res., 24, 473-482.

Bošel'a, M., Lukáč, M., Castagneri, D., Sedmák, R., Biber, P., Carrer, P. et al., 2018. Contrasting effects of environmental change on the radial growth of cooccurring beech and fir trees across Europe. Sci. Total Environ., 615, 1460-1469.

Bouriaud, O., Popa, I., 2009. Comparative dendroclimatic study of Scots pine, Norway spruce, and silver fir in the Vrancea Range, Eastern Carpathian Mountains. Trees, 23, 1, 95-106.

Bréda, N., Huc, R., Granier, A., Dreyer, E., 2006. Temperate forest trees and stands under severe drought: a review of ecophysiological responses, adaptation processes and longterm consequences. Ann. For. Sci., 63, 625-544.
Camarero, J.J., Gazol, A., Sangüesa-Barreda, G., Oliva, J., Vicente-Serrano, S.M., 2015. To die or not to die: early warnings of tree dieback in response to a severe drought. J. Ecol., 103, 44-57.

Caudullo, G., Tinner, W., de Rigo, D., 2016. Picea abies in Europe: distribution, habitat, usage and threats. In: SanMiguel-Ayanz, J., de Rigo, D., Caudullo, G., Houston Durrant, T., Mauri, A. (Eds.): European Atlas of Forest Tree Species. European Commission, pp. 114-116.

Čermák, J., Kučera, J., Bauerle, W.L., Phillips, N., Hinckley, T.M., 2007. Tree water storage and its diurnal dynamics related to sap flow and changes in stem volume in old-growth Douglas-fir trees. Tree Physiol., 27, 181-198.

Chan, T., Holtta, T., Berninger, F., Makinen, H., Nojd, P., Mencuccini, M., Nikinmaa, E., 2016. Separating waterpotential induced swelling and shrinking from measured radial stem variations reveals a cambial growth and osmotic concentration signal. Plant Cell Environ., 39, 233-244.

Dietrich, L., Zweifel, R., Kahmen, A., 2018. Daily stem diameter variations can predict the canopy water status of mature temperate trees. Tree Physiol., 38, 7, 941-952.

Eilmann, B., Rigling, A., 2012. Tree-growth analyses to estimate tree species'drought tolerance. Tree Physiol., 32, 178-187.

Ehrenberger, W., Rüger, S., Fitzke, R., Vollenweider, P., Günthardt-Goerg, M.S., Kuster, T., Zimmermann, U., Arend, M., 2012. Concomitant dendrometer and leaf patch pressure probe measurements reveal the effect of microclimate and soil moisture on diurnal stem water and leaf turgor variations in young oak trees. Funct. Plant Biol., 39, 297-305.

Ellenberger, H., 2009. Vegetation Ecology of Central Europe. Fourth edition. Cambridge University Press, Cambridge, UK.

Geburek, T., 2010. Larix decidua Miller, 1768. In: Roloff, A., Weissgerber, H., Lang, U., Stimm, B. (Eds.): Bäume Mitteleuropas. Wiley, Weinheim, pp. 431-450.

González-Rodríguez, Á.M., Brito, P., Lorenzo, J.R., Gruber, A., Oberhuber, W., Wieser, G., 2017. Seasonal cycles of sap flow and stem radius variation of Spartocytisus supranubius in the alpine zone of Tenerife, Canary Islands. Alp. Bot., 127, 97-108.

Gričar, J., Čufar, K., 2008. Seasonal dynamics of phloem and xylem formation in silver fir and Norway spruce as affected by drought. Russ. J. Plant Physiol., 55, 538-543.

Hartmann, H., 2011. Will a 385 million year-struggle for light become a struggle for water and for carbon? - How trees may cope with more frequent climate change-type drought events. Glob. Change Biol., 17, 642-655.

Hinckley, T.M., Lassoie, J.P., Running, S.W., 1978. Temporal and spatial variations in water status of forest trees. For. Sci. Monogr., 20, 1-72.

Hlásny, T., Barcza, Z., Fabrika, M., Balázs, B., Chirkina, G., Pajtík, J., Sedmák, R., Turčáni, M., 2011. Climate change impacts on growth and carbon balance of forests in Central Europe. Clim. Res., 47, 219-236.

IPCC, 2013. Stocker, T.F., Qin, D., Plattner, G.-K., Tignor, M., Allen, S.K., Boschung, J., Nauels, A., Xia, Y., Bex, V., Midgley, P.M. (Eds.): Climate Change 2013: The Physical Science Basis. Contribution of Working Group I to the Fifth Assessment Report of the Intergovernmental Panel on Climate Change. Cambridge University Press, Cambridge, UK.

IPCC, 2014. Climate Change 2014: Impacts, Adaptation, and Vulnerability. Part A: Global and Sectoral Aspects. Contribution of Working Group II to the Fifth Assessment Report of the Intergovernmental Panel on Climate Change. Cambridge University Press, Cambridge, United Kingdom and New York, NY, USA. 
Irvine, J., Grace, J., 1997. Continuous measurement of water tensions in the xylem of trees based on the elastic properties of wood. Planta, 202, 455-461.

Irvine, J., Perks, M.P., Magnani, F., Grace, J., 1998. The response of Pinus sylvestris to drought: stomatal control of transpiration and hydraulic conductance. Tree Physiol., 18, 393-402.

Ježík, M., Blaženec, M., Kučera, J., Střelcová, K., Ditmarová, K., 2016. The response of intra-annual stem circumference increase of young European beech provenances to 2012 2014 weather variability. iForest - Biogeosciences and Forestry, 9, 6, 960-969.

Kokfelt, U., Muscheler, R., 2012. Solar forcing of climate during the last millennium recorded in lake sediments from northern Sweden. Holocene, 2, 447-452.

Köcher, P., Horna, V., Leuschner, C., 2013. Stem water storage in five coexisting temperate broad-leaved tree species: significance, temporal dynamics and dependence on tree functional traits. Tree Physiol., 33, 817-832.

Körner, C., Basler, D., 2010. Phenology under global warming. Science, 327, 5972, 1461-1462.

Krakau, U.K., Liesebach, M., Aronen, T., Lelu-Walter, M.-A., Schneck, V., 2013. Scots Pine (Pinus sylvestris L.). In: Pâques, L.E. (Ed.): Forest Tree Breeding in Europe. Current State-of-the-Art and Perspectives. Springer, Dordrecht, New York.

Latreille, A., Davi, H., Huard, F., Pichot, Ch., 2017. Variability of the climate-radial growth relationship among Abies alba trees and populations along altitudinal gradients. For. Ecol. Manag., 396, 150-159.

Lindner, M., Garcia-Gonzalo, J., Kolstrom, M., Green, T., Reguera, R., Maroschek, M. et al., 2008. Impacts of Climate Change on European Forests and Options for Adaptation. European Forestry Institute, Joensuu, 173 p.

McDowell, N.G., Allen, C.D., 2015. Darcy's law predicts widespread forest mortality under climate warming. Nat. Clim. Change, 5, 669-672.

McDowell, N., Pockman, W.T., Allen, C.D., Breshears, D.D., Cobb, N., Kolb, T., et al., 2008. Mechanisms of plant survival and mortality during drought: why do some plants survive while others succumb to drought? New Phytol., 178, 719-739.

Mencuccini, M., Hölttä, T., Sevanto, S., Nikinmaa, E., 2013. Concurrent measurements of change in the bark and xylem diameters of trees reveal a phloem-generated turgor signal. New Phytol., 198, 1143-1154.

Nourtier, M., Chanzy, A., Cailleret, M., Yingge, X., Huc R., Davi, H., 2014. Transpiration of silver Fir (Abies alba mill.) during and after drought in relation to soil properties in a Mediterranean mountain area. Ann. For. Sci., 71, 683-695.

Oberhuber, W., Stumböck, M., Kofler, W., 1998. Climate-treegrowth relationships of Scots pine stands (Pinus sylvestris L.) exposed to soil dryness. Trees, 13, 19-27.

Oberhuber, W., Gruber, A., Kofler, W., Swidrak, I., 2014. Radial stem growth in response to microclimate and soil moisture in a drought-prone mixed coniferous forest at an inner Alpine site. Eur. J. Forest Res., 133, 3, 467-479.

Oberhuber, W., Hammerle, A., Kofler, W., 2015. Tree water status and growth of saplings and mature Norway spruce (Picea abies) at a dry distribution limit. Front. Plant Sci., 6, 703.

Oberhuber, W., Sehrt, M., Kitz, F., 2020. Hygroscopic properties of thin dead outher bark layer strongly influence stem diameter variations on short and long time scales in Scots pine (Pinus sylvestris L.). Agric. For. Meteorol., 290, Article
Number 108026. DOI: 10.1016/j.agrformet.2020.108026

Offenthaler, I., Hietz, P., Richter, H., 2001. Wood diameter indicates diurnal and long-term patterns of xylem water potential in Norway spruce. Trees, 15, 215-221.

Pataki, D.E., Oren, R., Katul, G., Sigmon, J., 1998. Canopy conductance of Pinus taeda, Liquidambar styraciflua and Quercus phellos under varying atmospheric and soil water conditions. Tree Physiol., 18, 307-315.

Perämäki, M., Nikinmaa, E., Sevanto, S., Ilvesniemi, H., Siivola, S., Hari, P., Vesala, T., 2001. Tree stem diameter variations and transpiration in Scots pine: an analysis using a dynamic sap flow model. Tree Physiol., 21, 12-13, 889-897.

Percival, D.B., Walden, A.T., 2000. Wavelet Methods for Time Series Analysis. Cambridge University Press, Cambridge UK.

Požgaj, A., Kurjatko, S., Chovanec, D., Babiak, M., 1993. Struktúra a vlastnosti dreva. $1^{\text {st }}$ Ed. Príroda, Bratislava, 483 p.

Rathgeber, C.B.K., Cuny, H.E., Fonti, P., 2016. Biological basis of tree ring formation a crash course. Front. Plant Sci., $7,734$.

Rösch, A., Schmidbauer, H., 2018. WaveletComp1.1: A guided tour through the R package. $58 \mathrm{p}$.

Ruosch, M., Spahni, R., Joos, F., Henne, P.D., van der Knaap, W.O., Tinner, W., 2016. Past and future evolution of Abies alba forests in Europe - comparison of a dynamic vegetation model with palaeo data and observations. Glob. Chang. Biol., 22, 727-740.

Scholz, F.C., Bucci, S.J., Goldstein, G., Meinzer, F.C., Franco, A.C., Miralles-Wilhelm, F., 2008. Temporal dynamics of stem expansion and contraction in savanna trees: withdrawal and recharge of stored water. Tree Physiol., 28, 469-480.

Schuster, R., Oberhuber, W., 2013. Age-dependent climategrowth relationships and regeneration of Picea abies in a drought-prone mixed coniferous forest in the Alps. Can. J. For. Res., 43, 609-618.

Spiecker, H., 2002. Tree rings and forest management in Europe. Dendrochronologia, 20, 1, 191-202.

Steppe, K., De Pauw, D.J.W., Lemeur, R., Vanrolleghem, P.A., 2006. A mathematical model linking tree sap flow dynamics to daily stem diameter fluctuations and radial stem growth. Tree Physiol., 26, 257-273.

Steppe, K., Sterck, F., Deslauriers, A., 2015. Diel growth dynamics in tree stems: linking anatomy and ecophysiology. Trends Plant Sci., 20, 335-343.

Teskey, R., Wertin, T., Bauweraerts, I., Ameye, M., McGuire, M.A., Steppe, K., 2015. Responses of tree species to heat waves and extreme heat events. Plant Cell Environ., 38, 9, 1699-1712.

Torrence, C., Compo, G.P., 1998. A practical guide to wavelet analysis. Bulletin of the American Meteorological Society, 79, 1, 61-78.

Turcotte, A., Rossi, S., Deslauriers, A., Krause, C., Morin, H., 2011. Dynamics of depletion and replenhishment of water storage in stem and roots of black spruce measured by dendrometers. Front. Plant Sci., 2, Article Number 21.

Usoltsev, V., Merganičová, K., Konôpka, B., Osmirko, A.A., Tsepordey, I.S., Chasovskikh, V.P., 2019. Fir (Abies spp.) stand biomass additive model for Eurasia sensitive to winter temperature and annual precipitation. Cent. Eur. For. J., 65, 166-172.

van der Maaten, E., van der Maaten-Theunissen, M., Smiljanić, M., Rossi, S., Simard, S., Wilmking, M., Deslauriers, A., Fonti, P., von Arx, G., Bouriaud, O., 2016. dendrometeR: Analyzing the pulse of tree in R. Dendrochronologia, 40, $12-16$. 
van der Maaten, E., van der Maaten-Theunissen, M., Smiljanić, M., Rossi, S., Simard, S., Wilmking, M., Deslauriers, A., Fonti, P., von Arx, G., Bouriaud, O., 2016. DendrometeR: Analyzing the pulse of tree in R. Dendrochronologia, 40, 12-16.

Vieira, J., Rossi, S., Campelo, F., Freitas, H., Nabais, C., 2013. Seasonal and daily cycles of stem radial variation of Pinus pinaster in a drought-prone environment. Agric. For. Meteorol., 180, 173-181.

Vitali, V., Büntgen, U., Bauhus, J., 2017. Silver fir and Douglas fir are more tolerant to extreme droughts than Norway spruce in south-western Germany. Glob. Chang. Biol., 23, 5108-5119.

Will, R.E., Wilson, S.M., Zou, C.B., Hennessey, T.C., 2013. Increased vapour pressure deficit due to higher temperature leads to greater transpiration and faster mortality during drought for tree seedlings common to the forest-grassland ecotone. New Phytol., 200, 366-374.

Zeidler, A., Borůvka, V., Schönfelder, O., 2018. Comparison of wood quality of douglas fir and spruce from afforested agricultural land and permanent forest land in the Czech Republic. Forests, 9, 1. DOI: 10.3390/f9010013

Zweifel, R., 2006. Intra-annual radial growth and water relations of trees: implications towards a growth mechanism. J. Exp. Bot., 57, 6, 1445-1459.
Zweifel, R., Häsler, R., 2001. Dynamics of water storage in mature subalpine Picea abies: temporal and spatial patterns of change in stem radius. Tree Physiol., 21, 561-569.

Zweifel, R., Item, H., Hasler, R., 2000. Stem radius changes and their relation to stored water in stems of young Norway spruce trees. Trees, 15, 50-57.

Zweifel, R., Item, H., Häsler, R., 2001. Link between diurnal stem radius changes and tree water relations. Tree Physiol., 21, 869-877.

Zweifel, R., Zimmermann, L., Newbery, D.M., 2005. Modelling tree water deficit from microclimate: an approach to quantifying drought stress. Tree Physiol., 25, 147-156.

Zweifel, R., Zimmermann, L., Zeugin, F., Newberry, D.M., 2006. Intra-annual radial growth and water relations of trees: implications towards a growth mechanism. J. Exp. Bot., 57, 1445-1459.

Zweifel, R., Drew, D.M., Schweingruber, F., Downes, G.M., 2014. Xylem as the main origin of stem radius changes in Eucalyptus. Funct. Plant Biol., 41, 520-534.

Received 4 December 2019 Accepted 7 July 2020 